\title{
Penatalaksanaan Periodontitis Kronik Pada Penderita Diabetes Mellitus
}

\author{
(Management of Chronic Periodontitis in Diabetes Mellitus Patients)
}

Victoria Dewanti Arifiana', Nabila Prandita'

1 Departemen Ilmu Penyakit Mulut Universitas Jenderal Soedirman

\begin{abstract}
Abstrak
Diabetes Melitus (DM) merupakan gangguan metabolisme yang dapat terjadi secara genetis dan klinis termaksuk heterogen dengan manifestasi berupa hilangnya toleransi kabohidrat. Salah satu komplikasi diabetes melitus di bidang kedokteran gigi adalah oral diabetic meliputi mulut kering, gusi mudah berdarah (gingivitis), kalkulus, resorbsi tulang alveolaris, dan periodontitis. Periodontitis adalah suatu penyakit peradangan jaringan pendukung gigi yang disebabkan oleh kelompok mikroorganisme tertentu yang biasanya berasal dari plak gigi yang dapat mengakibatkan penghancuran progresif jaringan ikat periodontal dan tulang alveolar dengan pembentukan saku, resesi, atau keduanya. Laporan kasus ini adalah untuk mempelajari penatalaksanaan periodontitis kronis pada penderita DM. Pasien wanita berusia 52 tahun datang dengan keluhan gigi belakang hilang dan berlubang ingin dilakukan perawatan. Pasien memiliki riwayat diabetes. Kejadian periodontitis pada DM mempunyai angka kejadian lebih besar, maka dari itu adanya kontrol glikemik memegang peran penting untuk mencegah perburukan yang ada.
\end{abstract}

Kata Kunci : Diabetes Mellitus, Infeksi Mulut, Periodontitis

\begin{abstract}
Diabetes mellitus (DM) is a metabolic disorder that can occur genetically and clinically, including heterogeneous with manifestations in the form of loss of tolerance for carbohydrates. One of the complications of diabetes mellitus in the field of dentistry is oral diabetes including dry mouth, gingivitis, calculus, alveolar bone resorption, and periodontitis. Periodontitis is an inflammatory disease of the tooth supporting tissue caused by a particular group of microorganisms usually derived from dental plaque which can result in the progressive destruction of the periodontal connective tissue and alveolar bone with pocket formation, recession, or both. This case report is to study the management of chronic periodontitis in DM sufferers. The 52-year-old female patient came with complaints of missing and perforated back teeth wanting treatment. The patient has a history of diabetes. The incidence of periodontitis in DM has a greater incidence rate, therefore the existence of glycemic control plays an important role in preventing any deterioration.
\end{abstract}

Keywords : Diabetes Mellitus, Oral Infection, Periodontitis

Korespondensi (correspondence) : Victoria Dewanti Arifiana, Universitas Jendral Soedirman, Purwokerto, email : drg.victoriadewanti@gmail.com

Periodontitis merupakan inflamasi destruktif pada jaringan periodontal yang disebabkan oleh mikroorganisme spesifik, yang mengakibatkan kerusakan ligament periodontal dan tulang alveolar dengan terbentuknya poket, resesi gingiva, maupun keduanya.' $\quad$ Periodontitis biasanya berkembang dari gingivitis yang terjadi perubahan komposisi dan potensi patogenik dari mikroorganisme plak terhadap resistensi host yang akan menentukan tingkat keparahan dari periodontitis. ${ }^{2}$ Etiologi dari periodontitis sangat kompleks, yaitu faktor lokal dan faktor sistemik. Umumnya periodontitis disebabkan faktor lokal seperti bakteri plak namun dapat diperparah dengan adanya faktor sistemik yang kurang menguntungkan seperti memiliki penyakit Diabetes Mellitus (DM). ${ }^{3}$ Diabetes Mellitus dapat menjadi faktor resiko terjadinya periodontitis dengan memperparah kerusakan jaringan periodontal. ${ }^{4}$ Terdapat hubungan timbal balik antara DM dengan periodontitis, dimana DM dapat meningkatkan berkembangnya penyakit periodontal, sebaliknya periodontitis juga dapat memperparah kontrol glikemik pada pasien DM. Perawatan periodontal dapat mempengaruhi kontrol glikemik dengan mengurangi bakteri dan respon inflamasi. ${ }^{4}$
Diabetes mellitus adalah suatu penyakit yang ditandai dengan kegagalan dan defisiensi pankreas dalam memproduksi insulin sehingga terjadi gangguan metabolik berupa hiperglikemik. 5 Tingginya kadar gula dalam darah yang melebihi normal dalam urin menjadikan DM sering dikenal dengan sebutan kencing manis. ${ }^{6}$ Dikatakan seseorang menderita DM jika kadar gula darah sewaktu $\geq$ $200 \mathrm{mg} / \mathrm{dl}$ dan kadar gula darah puasa $\geq 126$ $\mathrm{mg} / \mathrm{dl}$. Hal ini disebabkan karena kurangnya pembentukan atau keaktifan insulin yang dihasilkan sel beta dari pulau Langerhans di pankreas atau kerusakan pada pulau Langerhans itu sendiri. ${ }^{7}$

Berdasarkan penelitian yang dilakukan oleh Gregory (2011) bahwa keparahan periodontitis pada penderita DM lebih besar dibandingkan penderita non-DM terutama jika kontrol glikemik yang buruk. Dengan ditunjukan pada peningkatan kedalaman probing, indeks plak, indeks gingiva, kerusakan attachment serta kehilangan gigi.8 Manifestasi oral selain periodontitis pada pasien DM diantaranya adalah xerostomia, Stomatitis apthosa, rasa mulut terbakar, oral thrush dan karies. Tujuan pembuatan laporan kasus ini adalah untuk membahas mengenai pengaruh Diabetes Mellitus terhadap periodontitis serta 
tindakan dental yang dapat dilakukan pada pasien DM.

\section{LAPORAN KASUS}

Seorang wanita berusia 52 tahun datang ke RSGM Unsoed dengan keluhan gigi belakang hilang serta mengeluhkan gigi berlubang dan terdapat karang gigi sehingga ingin dilakukan perawatan. Pasien merasa tidak nyaman terutama saat makan dan gigi yang berlubang terdapat fistula pada mukosa bukal. Pasien memiliki riwayat Diabetes Millitus dari keturunan dan berat badan pasien yang melebihi batas (obesitas) yang terkontrol karena pasien mengikuti prolanis. Keseharian pasien menjadi ibu rumah tangga.

Pemeriksaan umum keadaan pasien kompos mentis. Pasien wanita, dengan tekanan darah 160/100 mm/Hg, pernafasan 20 kali per menit, nadi 70 kali per menit, suhu $36,5^{\circ}$ C. Berat badan $88 \mathrm{~kg}$ dan tinggi badan $176 \mathrm{~cm}$. Pemeriksaan ekstraoral menunjukkan tidak ada kelainan pada wajah, mata, leher, dan ekstremitas. Kelenjar getah bening di servikal tidak ditemukan adanya pembesaran.

Pemeriksaan intraoral menunjukkan adanya resesi dan kalkulus pada seluruh regio 3 dan 4, terdapat fistula pada gigi 24. Gigi posterior molar atas mengalami sisa akar, dan molar bawah hilang karena karies. Terdapat halitosis, Disertai pemeriksaan penunjang pengecekan gula darah dan rontgen panoramik. Berikut merupakan gambaran pemeriksaan penunjang.
Hasil anamnesa dan pemeriksaan klinis didapatkan OHIS $44 \%$ diagnosis Periodontitis Kronik Marginalis Generalisata disertai Diabetes Millitus. Pada kunjungan pertama selain pemeriksaan intraoral dan ekstraoral juga dilakukan pemeriksaan Tekanan Darah $160 / 100 \mathrm{mmHg}$ serta pemeriksaan penunjang. Pemeriksaan penunjang gula darah dalam keadaan puasa menunjukan hasil $143 \mathrm{mg} / \mathrm{dl}$ dan pemeriksaan radiologi panoramik menunjukan adanya resobsi tulang secara horizontal pada seluruh regio pada rongga mulut. Pada kunjungan pertama tindakan yang dapat dilakukan adalah memberikan edukasi mengenai perbaikan oral hygiene, sikat gigi,

Setelah 2 minggu pasien datang kembali untuk follow up. Pemeriksaan intraoral ditemukan adanya fistula pada gigi 24, pasien mengalami halitosis, tanpa xerostomia, sisa akar pada gigi 16,17,26 dan 27. Serta terdapat resesi pada gigi $31,32,33,41,42$, dan 43. Pemeriksaan tekanan darah menunjukan hasil $150 / 100 \mathrm{mmHg}$, dan pemeriksaan penunjang gula darah dalam keadaan puasa menunjukan hasil $163 \mathrm{mg} / \mathrm{dll}$. Terapi berupa pemberian edukasi kembali mengenai perbaikan oral hygiene dengan menggosok gigi $2 x$ sehari. Pada kunjungan ini, pasien tidak bisa dilakukan perawatan dental karena kadar gula darah dan tekanan darah pasien yang tinggi sehingga beresiko jika dilakukan tindakan dental. Diperlukan istirahat yang cukup, diet makanan dan konsultasi dengan dokter spesialis penyakit dalam untuk mengontrol kondisi pasien.

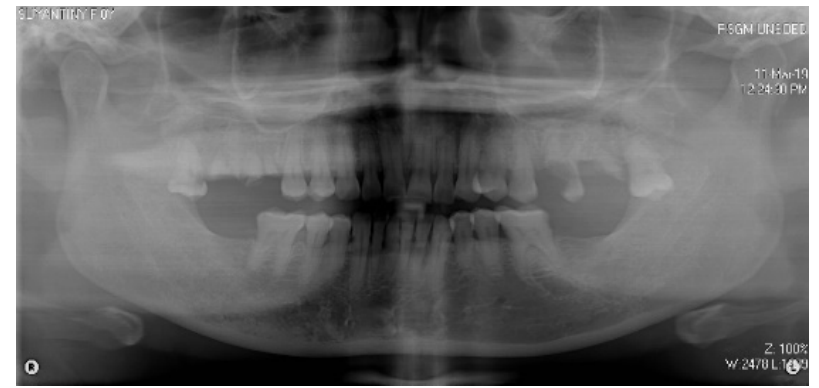

Gambar 1. Gambaran Foto Rontgent. Terdapat penurunan tulang horizontal berkisar 1/4 servical pada seluruh gigi rahang atas dan rahang bawah

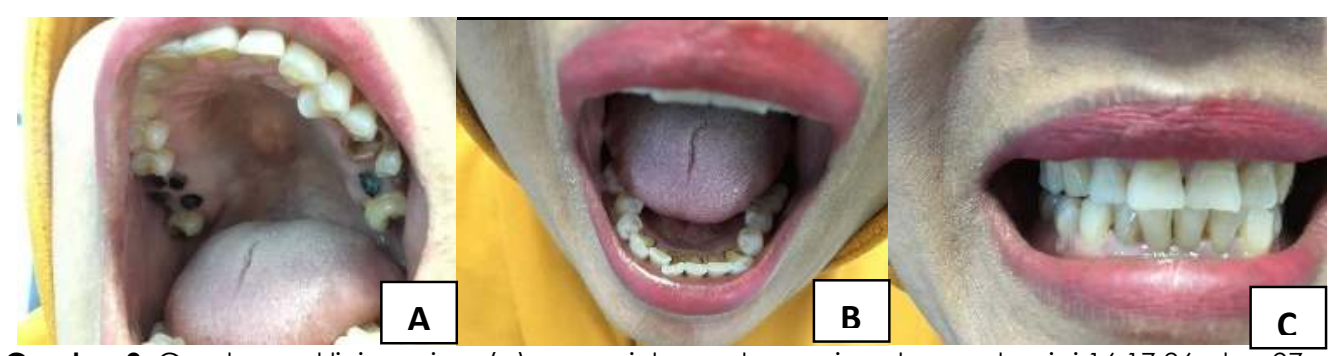

Gambar 2. Gambaran klinis pasien. (a) menunjukan adanya sisa akar pada gigi 16,17,26, dan 27, disertai adanya variasi normal berupa torus palatinus pada median palatum. (b) menunjukan adanya penurunan tulang pada anterior rahang bawah disertai dengan adanya kalkulus pada gigi

$33,32,31,43,42$, dan 41 . (c) kondisi pasien saat oklusi dimana terlihat adanya penurunan tulang pada anterior rahang bawah gigi 33,32,31,43,42, dan 41 . 


\section{PEMBAHASAN}

Diabetes mellitus merupakan penyakit metabolik yang memiliki karakteristik hiperglikemik yang terjadi karena kelainan sekresi insulin, kerja insulin ataupun keduanya. Gejala umum yang biasa terjadi pada pasien DM adalah polyuria, polydipsia, polifagia serta penurunan berat badan. Berdasarkan klasifikasinya DM dibedakan menjadi 2 yaitu tipe 1 Insulin Dependent Diabetes Mellitus (IDDM), dan tipe 2 Non-Insulin Dependent Diabetes Mellitus (NIDDM). 9 Insulin merupakan hormon protein yang disekresikan oleh sel beta langerhans di pankreas, insulin ini berfungsi sebagai reseptor bagi sel menerima glukosa, tanpa insulin glukosa tidak dapat masuk kedalam sel sehingga kadar glukosa dalam darah meningkat. 11

Diabetes Mellitus tipe 1 biasanya terjadi karena kerusakan sel beta pankreas, menyebabkan penderita kekurangan insulin secara absolut, disebabkan adanya reaksi autoimun. Penderita biasanya mudah mengalami ketoacidosis dan terjadi fluktuasi kadar gula darah plasma. ${ }^{10}$ Sedangkan Diabetes Mellitus tipe 2 penderita memiliki insulin dalam jumlah normal tetapi terjadi kekurangan reseptor insulin sehingga glukosa sulit masuk dalam sel, akibatnya sel kekurangan glukosa dan terjadi peningkaan gula darah. ${ }^{11}$

Komplikasi oral pada pasien DM menunjukan adanya luka yang sukar sembuh dan xerostomia, seperti halnya meningkatnya penyakit periodontal. 10 Penyakit periodontal telah ditetapkan sebagai komplikasi DM urutan ke enam. Menurut bridges dkk (1996) bahwa DM dapat mempengaruhi semua parameter periodontal, termasuk skor bleeding, probing depth, hilangnya perlekatan dan tanggalnya gigi. ${ }^{17}$

Periodontitis terjadi karena interaksi berbagai faktor, yaitu faktor mikroorganisme, lingkungan, metabolik, genetik dan status kebersihan rongga mulut. ${ }^{2}$ Periodontitis pada penyakit sistemik seperti DM lebih sering terjadi dan lebih parah, serta tidak selalu berhubungan dengan plak dan kalkulus. ${ }^{9}$ Pasien DM beresiko 3 kali lebih tinggi mengalami periodontitis dibandingkan penderita non-DM. perawatan periodontal seperti scaling dan root planning akan membantu dalam mengontrol kadar gula darah'. Sebaliknya apabila periodontitis tidak dirawat maka akan mempersulit kontrol gula darah dan memperparah periodontitis hingga kehilangan gigi. Kehilangan gigi akan menyebabkan penurunan kualitas hidup karena sulit dalam mencerna makanan serta penurunan fungsi estetis. Hal ini dapat disebabkan karena perubahan respon inflamatori terhadap bakteri patogen, berkurangnya aspek formatif proses metabolisme jaringan ikat, gangguan penyembuhan luka, perubahan mikrovaskuler dan pembentukan produk akhir glikasi (AGEs). ${ }^{9}$
Advanced glycation end products (AGEs) merupakan produk akhir glikasi yang terbentuk dari reaksi non enzimatik glukosa dan peningkatan oksidasi asam lemak. Produk glikasi ini akan berpengaruh pada peningkatan apoptosis osteoblas. DM juga mempengaruhi pembentukan tulang karena mengakibatkan penurunan ekspresi faktor transkripsi yang mengatur regulasi differensiasi osteoblas, reseptor AGEs juga meningkat pada osteoblas pasien DM menyebabkan pasien DM lebih sensitif terhadap AGEs. ${ }^{14}$ Terbentuknya AGEs yang berlebihan pada jaringan gingiva menyebabkan permeabilitas vaskuler yang lebih besar, kerapuhan serat kolagen dan terjadi kerusakan baik pada jaringan ikat nonmineralisasi dan tulang 4 .

Periodontitis dan DM memiliki hubungan yang kompleks dan berhubungan dengan mediator inflamasi. Dilakukan pencarian untuk biomarker periodontitis dan DM. ${ }^{15}$ salah satu faktor yang tidak dapat dimodifikasi dan berhubungan dengan DM dan periodontitis adalah variasi genetik individu (single nucleotide polymorphism atau SNP). Faktor ini akan menentukan respon imun host terhadap stimulus sekaligus menentukan apakah stimulus tersebut akan menyebabkan kerusakan atau tidak. ${ }^{16}$

Sebelum melaksanakan perawatan gigi dan mulut pada pasien DM perlu diperhatikan tipe perawatan menurut Sonis dkk (1995) berikut:

- Tipe I : pemeriksaan atau radiografi, instruksi $\mathrm{OH}$ dan pencetakan untuk model studi

- Tipe II : penambalan gigi sederhana, profilaksis dan perawatan orthodonsia

- Tipe III : penambalan lanjutan, perawatan endodontik, scaling dan root planning

- Tipe IV : pencabutan gigi sederhana, kuretase, dan gingivoplasti

- Tipe $V$ : pencabutan serial, bedah flap dan gingivektomi

- Tipe VI : bedah besar dan reseksi gingiva

Berdasarkan informasi yang dikumpulan, pasien dapat dikelompokan dalam kategori kelompok resiko spesifik, yaitu pasien resiko rendah, kontrol metabolik baik dengan obatobatan dalam keadaan stabil, asimptomatik, tidak ada komplikasi neurologik, vaskular maupun infeksi, kadar gula darah puasa $<200$ $\mathrm{mg} / \mathrm{dl}$ dan kadar $\mathrm{HbAlc}<7 \%$. Pasien pada golongan ini dapat dirawat dengan normal untuk prosedur perawatan gigi restoratif (tipe I sampai III), dan perlu perhatian khusus untuk kontrol diet, pengurangan stres, dan resiko infeksi seluruh prosedur bedah (tipe IV sampai VI).

Pasien resiko menengah, simtom yang sama namun, memiliki kondisi metabolik seimbang, tidak ada riwayat hipoglikemik dan ketoasidosis dan komplikasi diabetes yang terlihat, gula darah puasa tidak $>250 \mathrm{mg} / \mathrm{dl}$ dan konsentrasi HbAlc sekitar 7-9\%. Kontrol diet, mengurangi stres dan resiko infeksi sangatlah penting bagi pasien dengan 
standar resiko menengah. Pasien ini dapat menerima perawatan dental (tipe I sampai III) dengan protokol normal, tapi Teknik sedasi harus dipertimbangkan. Tindakan bedah menengah dan besar (tipe IV sampai VI) hanya dapat dilakukan setelah konsultasi dengan dokter yang merawat pasien.

Pasien resiko tinggi, memiliki banyak komplikasi dan kontrol metabolik buruk, sering mengalami hipoglikemik atau ketoasidosis dan membutuhkan injeksi insulin, glukosa darah puasa $>250 \mathrm{mg} / \mathrm{dl}$. Konsentrasi HbAl > 9\% dan mempunyai resiko tinggi terhadap perawatan gigi. Pasien ini dapat menerima perawatan dental setelah menerima perawatan pendahuluan untuk menurunkan stres. Seluruh tindakan perawatan dilakukan bila kondisi medis dalam keadaan stabil. Pada pasien terkontrol tetapi mengalami infeksi gigi aktif maka tindakan yang dilakukan berupa kontrol infeksi.

Pada kasus ini, diagnosis definitif periodontitis kronik yang diperberat DM ditegakkan berdasarkan anamnesis dan pemeriksaan klinis. Anamnesis diketahui adanya rasa tidak nyaman karena gigi berlubang yang berujung gigi hilang pada gigi belakang bawah kanan dan kiri, pasien juga mengaku memiliki riwayat DM sejak 4 tahun lalu dengan didukung obesitas tubuh namun rutin kontrol mengikuti prolanis dan menjalani diet. Gambaran klinis menunjukan kalkulus pada region 3 dan 4, terdapat kehilangan gigi pada posterior rahang bawah, terdapat resesi gingiva pada area gigi anterior rahang bawah, sensasi mulut terbakar dan xerostomia tidak ditemukan. Kadar GDS dalam keadaan puasa pada kunjungan pertama $143 \mathrm{mg} / \mathrm{dl}$ dan kunjungan kedua GDS dalam keadaan puasa $163 \mathrm{mg} / \mathrm{dl}$. Pasien diberikan edukasi untuk memperbaiki oral hygiene, melanjutkan konsumsi obat DM serta cara diet DM untuk menurunkan kadar gula darahnya. Namun demikian, kadar GDS pada kunjungan kedua tidak ada penurunan sehingga diperlukan konsultasi dengan dokter penyakit dalam yang merawat DM sebelum dilakukan perawatan dental.

Diabetes Mellitus merupakan salah satu faktor resiko terjadinya periodontitis yang menyebabkan kerusakan jaringan periodontal. Keparahan periodontitis pada penderita Diabetes Mellitus lebih besar dibandingkan penderita non Diabetes Mellitus terutama jika kontrol glikemik yang buruk. Penanganan dental pada penderita Diabetes Mellitus dilakukan berdasarkan pengelompokan resiko pasien.

\section{DAFTAR PUSTAKA}

1. Saini R., Saini S., Saini SR. Periodontal Disease: A Risk Factor to Cardio Vascular Disease. Annuals of Cardiac Anaesthesia, 2013; 13 (2): 159-61.

2. Salama Rl. Association Between Periodontal Disease and Cardiovascular
Disease, Pak J Med Sci, 2011 ; 20 (2): 1516.

3. Mirza M., Mengenali Diabetes, Pustaka Hidayah, 2016,(10-15)

4. Preshaw PM., Alba AL., Herrera D., Jepsen S., Konstantinidis A., Makrilakis K., Taylor R. Periodontitis and Diabetes: a Two-Way Relationship. Diabetologia. 2012; 55 (1): 21-31

5. Wu YY., Xiao E., Graves DT. Diabetes Mellitus Related Bone Metabolism and Periodontal Disease. Int J Oral Sci, 2015; 7(2): 63-72

6. Carnu O., Kamer A.The Influence of DM on the Periodontal Tissue., J. Am Dent Ass. 2013; 143: 345-405

7. Hanes P.J., Krishna R. Characteristic of Inflammation Common to Both Diabetes and Periodontitis: are Predictive Diagnosis and Targeted Preventive Measures Possible. EPMA Journal. 2010; 1: 101-6

8. Newman MG., Takei HH., Klokkevold PR., Carranza FA.Carranza's Clin Periodontology, 12th Ed, Elsevier, Canada. 2013

9. Boedi S., Mengenal Kelainan Dalam Mulut yang Menyertai Diabetes Mellitus, Jurnal IImiah dan Teknologi Kedokteran Gigi Universitas Prof. DR. Moestopo. 2013; 1(2): 1639-7039

10. Martin MD. Epidemiologi dan Etiologi Penyakit Periodontal, Cermin Dunia Kedokteran 72. 2010

11. Saidina., Hubungan Timbal Balik Antara Periodontitis Dengan Diabetes Mellitus. Dentika Dental Journal, 2012; 8 (2): 120-5

12. A. Boedisantoso., BukU Ajar Praktis Metabolic Endrokrinologi Rongga Mulut, UI Press, Jakarta. 2012

13. Aru W Sedoyo., Buku Ajar Penyakit Dalam, Jilid I Edisi ke 3, FKUI, Jakarta. 2013

14. Gregory K., Periodontal Status of Diabetic and Non Diabetic Men: Effect of Smoking, Glycemic Control, and Sosioeconomic Factors. J. Periodontol, 2013; 67: $1185-92$

15. Oates TW. Diabetes Mellitus and Periodontal Disease. J.Periodontol,2014; 77 (8)

16. Celvin CM. The Relationship Between Diabetes and Periodontal Disease, J Can Dent Assoc, 201568 (3): 161-4 
Penatalaksanaan Periodontitis Kronik Pada Penderita Diabetes Mellitus ... (Arifiana dan Nabila)

17. Athur B., Novaes Jr., Sergio LS., Souza., Marcio F.M.G. Effect of Non Surgical Periodontal Therapy on Glicemic Control in Patient with Type 2 Diabetes Mellitus, $J$ Periodontal, 2014, 74: 1361-7 